\title{
FACTORS AFFECTING THE IMPLEMENTATION OF NURSE THERAPEUTIC COMMUNICATION TO PATIENTS TREATED AT SANT ANTONIUS PONTIANAK GENERAL HOSPITAL DURING THE COVID-19 PANDEMIC
}

\author{
Dwi Kurniasih, Antonius Jumadi, Elisabeth Wahyu Savitri
}

Nursing Academy Dharma Insan, Pontianak, West Kalimantan

\begin{abstract}
Background: The nurse-client relationship is a reciprocal relationship that is mutually beneficial in nursing care. All actions, thoughts, words, and interventions performed by nurses become therapy for the client's recovery. This study aimed to factors affecting the implementation of nurse therapeutic communication to the patients treated at Sant Antonius Pontianak General Hospital during the COVID-19 pandemic.
\end{abstract}

Subjects and Method: This was a cross-sectional study conducted at Santo Antonius General Hospital, Pontianak, West Kalimantan, from May 01 to 31 2021. A sample of 154 hospital nurses was selected for this study. The dependent variable was therapeutic communication. The independent variables were age, gender, education, work position, and length of work. The data were collected by questionnaire. The data were analyzed by odds ratio and chi-square.

Results: The therapeutic communication in hospital nurses was associated with age $(\mathrm{OR}=1.08 ; 95 \% \mathrm{CI}=0.19$ to $6.11 ; \mathrm{p}=1.000)$, female $(\mathrm{OR}=0.57 ; 95 \% \mathrm{CI}=0.36$ to 0.89 ; $\mathrm{p}<0.001)$, education $(\mathrm{OR}=1.41 ; 95 \% \mathrm{CI}=1.00$ to $1.07 ; \mathrm{p}=1.000)$, COVID-19 patient care $(\mathrm{OR}=1.09 ; 95 \% \mathrm{CI}=1.01$ to $1.17 ; \mathrm{p}=0.009)$, and longer work experience $(\mathrm{OR}=$ $0.96 ; 95 \% \mathrm{CI}=0.93$ to $0.99 ; \mathrm{p}=1.000$ ).

Conclusion: The therapeutic communication in hospital nurses is associated with age, female, education, COVID-19 patient care, and longer work experience.

Keywords: therapeutic communication, hospital, nurses

\section{Correspondence:}

Dwi Kurniasih. Nursing Academy Dharma Insan, Pontianak. Jl Merdeka 55 Pontianak, West Kalimantan. Email: dwi.kurniasih@akperdharmainsan.ac.id. Mobile: +62 81351607978. 